\title{
BRISMES \\ British Society for Middle Eastern Studies
}

\section{New Middle Eastern Studies}

Publication details, including guidelines for submissions: http://www.brismes.ac.uk/nmes/

\section{White Flag of Resistance Author(s): Yonatan Mendel}

To cite this article: Mendel, Yonatan, 'White Flag of Resistance', New Middle Eastern Studies, 1 (2011), <http://www.brismes.ac.uk/nmes/archives/727>.

To link to this article: http://www.brismes.ac.uk/nmes/archives/727

Online Publication Date: 20 December 2011

\begin{abstract}
Disclaimer and Copyright
The NMES editors and the British Society for Middle Eastern Studies make every effort to ensure the accuracy of all the information contained in the e-journal. However, the editors and the British Society for Middle Eastern Studies make no representations or warranties whatsoever as to the accuracy, completeness or suitability for any purpose of the content and disclaim all such representations and warranties whether express or implied to the maximum extent permitted by law. Any views expressed in this publication are the views of the authors and not the views of the Editors or the British Society for Middle Eastern Studies.
\end{abstract}

Copyright New Middle Eastern Studies, 2011. All rights reserved. No part of this publication may be reproduced, stored, transmitted or disseminated, in any form, or by any means, without prior written permission from New Middle Eastern Studies, to whom all requests to reproduce copyright material should be directed, in writing.

\section{Terms and conditions:}

This article may be used for research, teaching and private study purposes. Any substantial or systematic reproduction, re-distribution, re-selling, loan or sub-licensing, systematic supply or distribution in any form to anyone is expressly forbidden.

The publisher does not give any warranty express or implied or make any representation that the contents will be complete or accurate or up to date. The accuracy of any instructions, formulae and drug doses should be independently verified with primary sources. The publisher shall not be liable for any loss, actions, claims, proceedings, demand or costs or damages whatsoever or howsoever caused arising directly or indirectly in connection with or arising out of the use of this material. 


\title{
NEW MidDle EASTERN REVIEWS
}

\section{White Flag of Resistance}

\author{
The Secret Life of Saeed the Pessoptimist \\ Emile Habiby, translated by Salma Khadra Jayyusi and Trevor Le Gassick \\ London, Arabia Books, 2010, xxii + 169 pp., £7.99, Paperback \\ ISBN: 9781906697266
}

\author{
al-Waqā' i' al-Gharbiyya fì Ikhtifā' Sa 'īd Abī al-Naḥs al-Mutashā'il \\ Imīl Habīî̄i \\ Haifa, Dar Arabesque, 2006, 226 pp., 40 shekels, Paperback \\ ISBN: 9657388015
}

\author{
ha-Opsimist: ha-Khroniḳa ha-Mufla'ah shel He'almut Sa id Abu al-Naḥs al-Mutasha'il \\ Imil Habibi, translated by Anton Shammas \\ Tel Aviv, ha-Kibuts ha-Me'uhad, 1995, 159 pp., 64 shekels, Hardback
}

\section{BY YONATAN MENDEL}

Postdoctoral Researcher, Department of Politics \& Government, Ben Gurion University of the Negev; email: mendely@post.bgu.ac.il

"Conquerors, my son, consider as true history only what they have themselves fabricated." With these words, Saeed's former schoolteacher gives his Pessoptimist student a lesson in history. Saeed, a young Palestinian man, who during the 1948 War fled to Lebanon, has managed to return to Palestine, his homeland, which meanwhile has become the State of Israel. He is taken to Al-Jazzār Mosque in Acre, surrounded by fellow Palestinians, as well as his former teacher, who will all be deported the next morning. All, except Saeed the Pessoptimist. Saeed, the naïve, innocent, ill-fated Palestinian, due to his optimistic-pessimistic nature, is staying in the newborn Jewish country, and will become a Palestinian citizen of Israel. He is here to tell us his story. Not the official fortified history which is fabricated by the conquerors, but a personal, cynical, and powerful account of the ongoing Palestinian tragedy.

Emile Habibi's "The Secret Life of Saeed the Pessoptimist" is a masterpiece by any measure, and not only due to its tragic, frightening, ongoing relevance to life in Israel and the Occupied Palestinian Territories. Habibi, himself a Palestinian citizen of Israel, was born in Haifa, Palestine, and buried in Haifa, Israel. He was a talented man: a politician of the joint Jewish-Palestinian Communist Party, a poet, a writer, a journalist, a literary critic. But one can argue that above all, The Pessoptimist is his greatest creation.

Written in 1974, Habibi's book takes readers on a historical, poetic and political journey throughout the Middle East and into Palestine and Israel. Deploying the Mamluks, the Crusaders and Genghis Khan as an appropriate regional context, resurrecting al-Mutannabī, Ibn Firnās, and Khalil Gibran, and corresponding with Shakespeare, Voltaire, Orwell and Hašek, Habibi tells the 
story of the Palestinian citizens of Israel in a most honest, humble, comprehensive, and clever style. Great Palestinian intellectuals, such as Samih al-Qasim, Mahmoud Darwish and Taufiq Ziad, are all part of this book, set as gems in an uplifting and heartbreaking collage of the Palestinian people. Trying to survive and resist, to remain and protest, to combine hope in despair, optimism in pessimism, Habibi's pessoptimism is what many have wanted to say but lacked the words, or the courage.

From the book's very beginning Habibi exposes his particularly sensitive, anti-heroic, position. He tells how local newspapers advertised the names of all Arab notables arrested in Haifa, and merely gave reference "to the rest." "The rest - yes, that's me," writes Saeed, "those like me are everywhere - towns, villages, bars, everywhere. I am 'the rest." Elsewhere, when Saeed meets fellow Palestinians just after they have been evicted from their homes, he is asked whether he has met anybody from their villages. They mention names which up until today are a silent memory for the Palestinian Nakba: Kuwaykāt, Iqrit, al-Șafșāf, Suḥmātā, Dayr al-Qāsī. Saeed, though, breaks all rules regarding the sacred way with which these places are treated. "I was much tickled at the repetition of the ' $k$ ' in Kuwaykāt but managed to suppress my laughter," he says in a Forrest Gump style. Regarding the other villages, Saeed just asks the readers not to expect him to remember their names. "After all," he says sarcastically, "we of Haifa used to know more about the villages of Scotland than we did about those of Galilee."

Saeed's anti-heroic comments open a window into the lives of the "silent majority" found behind the big stories of resistance. He is a Palestinian citizen of Israel, who due to his father's collaboration with the Zionist movement receives the "privilege" of staying in Israel and working as an informer for the state. This is an interesting positioning which enables us to see the Palestinian struggle not through the eyes of the heroes, the combatants, and the great orators, but through Saeed, a person paid by Israel, who shut his eyes embarrassingly when his beloved girl checked whether he was still awake, who stood paralysed when watching an Israeli officer pointing a gun at a mother and baby, who is afraid, and oppressed, and concerned - who is real.

Habibi gives his protagonist other tools than those usually praised and acknowledged in national struggles. He does not see the blunt, direct, confrontation as the only way to resist, and he does not believe that using politically-loaded terms, even if accurate, is always necessary. Instead he equips Saeed with a different arsenal: a deeply sarcastic sense of humour, an ability to juggle with as many linguistic clubs as required, and a fantastic capacity for dreaming.

The humour, driven by Saeed's youthful character that puts him into some impossible situations, is one of the most lethal weapons of the protagonist. It enables him to penetrate our hearts, to be as sharp and critical as possible, and to stay alive. When he is being investigated by the "big man," the boss of his boss, an Ashkenazi human metaphor of the Israeli administration (or even the Israeli security apparatus) Saeed naively assumes that he is blind due to the sunglasses he wears, and also deaf due to his habit of shouting. Saeed, then, in what reads like a combination of Adel Imam and Mr. Bean, gets closer and closer to the "big man" and eventually shouts into his ear. Yes, he is slapped by his Jewish boss, but the reward is visible: an explicit ridiculing of the authority figure and an implicit critique of Israel as a violent, militaristic, state which is blind to its citizens and deaf to their concerns.

Saeed relates manifold anti-militarist anecdotes about Israeli society, and he shoots his "unintentional" arrows straight into the heart of the Israeli political establishment and its rationale. For example, when telling readers about his extended family Saeed brags about his genealogy and says that he is a member of the "Pessoptimists", a group of Palestinian people who like him share an ill-fated faith in Israel, and whose reaction to this is a struggle of survival 
and resistance undertaken with optimism and pessimism. He sarcastically recalls one member of his family, who was "the first Arab to be appointed by the government of Israel as head of the Committee for Distribution of Dandelion and Watercress in Upper Galilee." The combination of Saeed's childish excitement on the one hand, and the long and meaningless title on the other, creates a bitter-sweet moment, one of many orchestrated by Habibi.

Through his different and powerful narrative modes Habibi demonstrates how the state tries to control the Palestinians living in Israel by giving them false promises, allowing them only theoretical access to capital, and providing them with fictitious, marginal and deceitful political duties. Habibi never points this out directly, but the views visible from the book's windows are filled with examples: from the subordinate essence planted in Saeed's language (he even calls his readers "my very fine sir"), through his marriage to a girl from Jisr al-Zarqā' that was allowed by the "big man" only in order to find out who were the sixteen "ungrateful" villagers who voted for the Communist Party in Jisr al-Zarqā", and up to the "heroic" struggle of the kibbutzim to stop the curfew on Palestinian villages, which was made not for moral reasons but only due to their concern for their crops and their urgent need for Palestinian labour.

As the cynical, critical, funny and tragic themes of the book diverge and re-converge to correspond harmoniously once again, it seems that Habibi is an artist of words more than anything else. Like Leonardo da Vinci who said, "I do not sculpt an image, I simply reveal what is hidden inside the stone," there is a feeling that Habibi also did not write a book, but rather helped this epic story to reveal itself. The names given, the terminology chosen, the expressions used, the pauses indicated, and the jokes made seem to be the outcome of a scrupulous process, in which every word was weighed before being placed in this wonderful mosaic.

The stylistic and linguistic complexity of the work ensures that the translator's task is not easy, and there will evidently be differences of opinion concerning how this text could be most suitably rendered into English. However, and bearing in mind that this is the fourth edition of the English translation, this cannot serve as an excuse for some of the translation inaccuracies and shortcomings. For example, the very name of the protagonist, Saeed, which means "happy" in Arabic, is explained far too late - in the third and final part of the book. Similarly, the original title of the book (accurate translation: "The Strange Circumstances surrounding the Disappearance of Sa ' $\overline{1}$ d the Ill-Fated Pessoptimist") is translated arbitrarily as "The Secret Life of Saeed the Pessoptimist," with no mention of the "strange circumstances", or of his "disappearance". Unfortunately, the Arabic name of the book is not given anywhere.

Some of the Arabic words are left un- or mis-translated, and hence lose their significance. For example, when Saeed sees the person with the lighthouse figure, it takes place in the "Fakhura Quarter." Fakhūra, meaning "proud" in Arabic, is an important hint not given to the English readers. The same with "Safsarsheck," Saeed's immediate boss, a Mizrahi Jew, about which the translator explains: "in Hebrew this name means broker." "Safsar" in Hebrew means "profiteer" more than anything and the name in un-Arabized Hebrew is actually Safsarchick. This is important as the suffix "chick" is a Yiddish diminutive which has penetrated modern Hebrew. Without these explanations, English readers cannot fully appreciate Habibi's criticism of Mizrahi Jews trying to make a little profit in light of their new social status - below Ashkenazi Jews but above Palestinian citizens. Neither will they notice that Habibi is highlighting the way that Yiddish-Ashkenazi terminology, and perhaps narrative, dominates the life and very being of Israeli Mizrahi Jews.

Moreover, and I emphasise these points as precise language is so critical to Habibi's writing, the book has constant inconsistencies with transliteration, and also includes some 
strange examples of over-translation. For example, one could question the decision to title the pre-Islamic period "The Age of Ignorance," without giving the Arabic term Jāhiliyya, to translate the name of the village Bāqa al-Gharbiyya as literally "West Baqah," or to call alJazzār Mosque as "The Jazzar Mosque" (and without mentioning that Jazzār in Arabic means "butcher", a shortcoming which relates to the problem of under-translation mentioned before). These shortcomings are especially obvious when one reads the English translation in comparison with the Hebrew translation of Anton Shammas, a Palestinian citizen of Israel, a poet and a writer. His translation, described by Prof. Sasson Somekh as a "linguistic miracle", is indeed a work of art which was made with great political, social and linguistic care. It can be argued that the translation of Habibi's work is a project that needs to be conducted by more than professional translators, but by artists and intellectuals like Shammas.

Despite these language- and translation-related shortcomings, the English translation reads well, and the translator's comments in the introduction to the 2011 edition are useful. Readers are also given some basic translations and clarifications of choices made by the author, such as the names of the main female characters. Saeed's first love is Yuaad, meaning in Arabic "to be returned," and the name of his second beloved is Baqiyya, "she who has remained." By being aware of the translations of these names the reader can relate not only to the fundamental issues of the Palestinian struggle - of remaining in the homeland or yearning to come back to it but can also realise the covert way in which Habibi sticks out his tongue at the Israeli administration. For example, when Saeed's son is born, a similar process of name-meaningresistance takes place. Saeed decided to name him Fathi, meaning "my conquest/victory" in Arabic, but his boss doesn't approve. Then, looking in the eyes of the "big man" - and alluding to Orwell's 1984 - the protagonist decides to name him Walaa, which means "loyalty." The "big man," as happy with the "loyalty" concept as Israel is today (see, for example, the Loyalty Oath Bill proposed by Foreign Minister Avigdor Lieberman), is not aware of the twist Habibi makes: by planting "loyalty" in his son's name, Saeed is about to make him loyal indeed - to the Palestinian cause, the struggle for independence, the end of occupation and the return of the refugees.

Habibi's play on words is important for the subtle way in which he depicts history. While most of today's writings about the Israeli-Palestinian conflict must include "Nakba," "occupation," "right of return," "refugees" or "settlements," Habibi makes a deliberate decision to speak about these concepts without using their well-known political names. Perhaps aware of the loaded meanings they carry, Habibi decides to depict them, and even shape them, but never to jump into the already heated pool, in which all expressions have ready-made meanings. Hence, Habibi looks at the Palestinian dispossession of 1948 through actual stories, such as that of the mother and baby from Berwa who were caught by the military governor, who bluntly shouted at them: "to the East... go to the East." In another part, Saeed depicts the half-full cups of coffee he found in Arab houses in Haifa following the 1948 War, in a scene which became unforgettable following the movie The Time That Remains, another Palestinian masterpiece made by Ilia Suleiman. In another part, Habibi depicts the events of the Palestinian disaster as "the first misfortunes of 1948," sarcastically alluding to future misfortunes. In another he just calls it: "1948, the devil-cursed year."

Habibi chooses his words carefully. In one sentence we can find alleged contradictions, which are still able to complete each other. "During the Six Day War, some years after the Tripartite Aggression, which came after the War of Independence" is one example, in which Habibi uses a Zionist term, then an Arab one, and then comes back to Zionist terminology. This 
does not mean that his protagonist identifies with Zionism, but instead it is an attempt to highlight the irony embedded in these popular phrases of ours. Habibi wants us to ask whose independence? Or how come the aggression of the Six Day War is not mentioned? Or what happened to the people of the West Bank and Gaza Strip following those six days?

It is this exploitation of linguistic ambiguity and the irony behind the text which made Habibi such an elusive writer, not being easily identified, hated or loved. Israel, for example, the country which refuses to accept any responsibility for the Palestinian dispossession, or to acknowledge the deliberate evacuation of Palestinians from their houses, awarded Habibi the Israeli Prize in Literature, the most important honour it can give in this field. The decision created a heated debate in Israel, and a former winner of the prize protested and returned his award to the committee.

Eventually Habibi was given and accepted the honour, which gave rise to another heated debate, now among Arab critics. Many of them perceived Habibi's decision as nothing but a betrayal. They saw him as a traitor, and perceived his protagonist Saeed as nothing but a shallow reflection of Habibi's alleged conformism to the inferior life of Palestinians in Israel. Following his acceptance of the prize, a Palestinian newspaper even accused him of assisting the Zionist movement to purchase weapons from Czechoslovakia during 1948. On the other hand, prominent Arab writers such as the Syrian poet Adonis, the Egyptian Nobel Prize-winner Naguib Mahfouz, and the Sudanese novelist Tayeb Salih, all supported him, encouraged his decision to receive the Israel Prize, and did not join the circle of critics.

Habibi never regretted the controversies he caused. When visited by Prof. Sasson Somekh, who recommended him to win the Israeli prize, he was asked whether he was angry for being put in such a position. Habibi, according to Somekh, was angry only about the question. He said that being read and respected by Israelis was one of the reasons which encouraged him to translate his book into Hebrew.

In this case, but also in others, Habibi remained loyal to his originality, to his unique thinking and writing, creativity and non-conformity. He demonstrated this also when deciding to use the Pessoptimist not only in order to criticise the obvious villain - the state of Israel which occupies the Palestinian territories/homeland - but also to aim sophisticated arrows of criticism at his society, and at the Arab countries and leaders. For example, when Saeed went to see his previous family house in Haifa, now occupied by Jewish-Israelis, he arrived and saw that the man was helping his wife to carry the laundry. He then ran away terrified, saying to himself, "This must be a trick. Why else would a man bring in the family laundry? This was never done by my father." In another part he speaks about the Arab princes who enjoy wine so much and especially the wine made in the Jewish colony of Zikhron-Ya'akov. Straightforward criticism is sent by Habibi also to the leadership of the Palestinian movement. "Those Arabs who stayed, stoically, in land occupied by our state," Saeed plays with words again, "received never so much as a mention in all the files of Ahmad Shukairy's ringing speeches."

This ability of Habibi to remain original, critical and honest seems unique in our political world composed of individuals who want to belong, to be categorised together, to share similar beliefs and political methods. Instead, Habibi remains loyal to his ideas, to his common sense, as if disconnected from the stirring streams outside. Perhaps his ability to dream, which he bequeaths to his protagonist Saeed, is one of his ways of doing so. The book is actually written to us as letters from "another place" and this is an indication of the unique viewpoint chosen by Habibi. From the very beginning the protagonist is aware that the "big man" and the Israeli thought police have one obvious disadvantage: "They cannot detect my meetings with the man 
from outer space", he says and so means they cannot penetrate his thoughts and imagination. This early realisation that an escape to another dimension is possible, that thoughts and dreams and plans and hopes can be a way to survive, accompanies Saeed and helps him. The sea, then, and nature generally, are revealed as efficient remedies, even if personal, for the cruelty and harshness of the state.

The fantastical dimension also helps Habibi to describe the hidden contents of his soul, and gives freedom to concepts that realistic descriptions cannot convey. The interchanges from dreams to reality, from illusions to real life, help Saeed to carry on and to share with his readers his most sincere fears and feelings. His nightmare, in which he sits on top of a blunt stake, without the ability to move or to look down, is a dramatic description. When he wakes up and realises it was a nightmare he adds another level to it and asks himself, and the readers, why one should stay on the stake if jumping and staying lead to the same result? He then thinks about a magical option, of sending a rope to the clouds, just like the "Indian magicians," but then comments sadly and sarcastically that "I am no Indian magician, just an Arab who had remained, by some magic, in Israel."

Habibi, who also served as a Palestinian Member of the Knesset for the Israeli Communist Party from 1953 to 1965, wrote other books, and also helped to re-establish the Palestinian press and literary criticism following the "devil-cursed year" of 1948. However, it seems that "the Pessoptomist," even in English, even today, is a beating heart, humane and real, part and parcel of the Palestinian people's being. Despite his death in 1996, Habibi "stayed in Haifa" as he asked to be written on his gravestone the Arabic word "Baqā," which in Hebrew translates to both "stays" and "stayed," probably as just another message of perseverance sent to the Zionist movement, playing with words until his very end.

One last and most funny and heartbreaking scene from "the Pessoptomist" is the moment when Israeli radio announces in Arabic in 1967 that all "defeated Arabs" should raise white flags. Saeed the Pessoptimist then hurries up and waves a white sheet put on a broomstick out of his window in the middle of Haifa. The radio announcement is aimed at Palestinians in the West Bank and the Gaza Strip, which were then occupied, but Saeed, through his pseudo-naïvety and wise-foolishness reminds us that the Palestinians in Jenin and Haifa and London are one. With this act, he sends a message that is still relevant thirty-seven years after the book was written: that a more just solution than two separate states (Israel and Palestine) is needed in order to bring the different parts of the Palestinian people together. Habibi also signals to us, with his pen and his words and a white sheet on a broom, that as long as the Palestinian people remain secondclass citizens in a "Jewish state," and as long as Saeed's family are scattered around the world, Haifa, like Jaffa, like Israel and like Palestine, would be spaces full of white flag: bright reminders of the responsibility not taken by Israel, of its refusal to see the Palestinians, and of the tragedy that this country brings to its own people and to those living under its occupation. Despite the forty-four years that have passed since this scene, it seems that Habibi's insights are as relevant today as ever. 